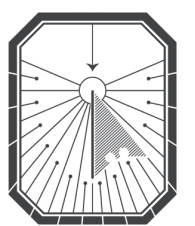

KYIV-MOHYLA HUMANITIES JOURNAL

KYIV-MOHYLA SCHOLARLY PEER-REVIEWED JOURNALS

Interconfessional Polemics in a Model of Ukrainian Literary History

Author(s): Ihor Isichenko

Source: Kyiv-Mohyla Humanities Journal 7 (2020): 27-44

Published by: National University of Kyiv-Mohyla Academy

http://kmhj.ukma.edu.ua/ 


\title{
Interconfessional Polemics in a Model of Ukrainian Literary History
}

\author{
Ihor Isichenko, Archbishop \\ V. N. Karazin Kharkiv National University, \\ Department of History of Ukrainian Literature
}

\begin{abstract}
Polemic texts on issues of Orthodox-Catholic relations occupy, for various reasons, a prominent place among publications in Ukrainian literature of the late 16 th - early 17 th centuries. Because of this, researchers of the history of Ukrainian literature continue to be interested in them. The history of the study of interconfessional polemics depends to a large extent on political contexts, primarily on the national and religious policies of states. Objective interpretation of polemical prose of the late 16th to the early 18 th centuries, however, warrants exemption from the influence of this state of affairs and the transfer of the focus of attention to the plane of literary communication. In such a context polemical texts can be seen as a manifestation of societal dialogue, reflecting the search of Ukrainian Baroque writers for their identity in the context of a civilizational dialogue between East and West and in geopolitical changes of the Reformation era.
\end{abstract}

Key Words: Interconfessional polemics, Ukrainian literature, Polish-Lithuanian Commonwealth, Baroque, literary dialogue, national identity.

Polemical prose belongs to the body of most studied Ukrainian literary texts of the early modern epoch. There are several reasons for this. The first and probably most important of them is the objective importance of polemical texts in the national discourse of the late 16 th - early 17 th centuries. Oleksandr Biletskyi determined the surviving works to number 140, of which 80 reflect the Catholic position and 6o the Orthodox, together constituting "an entire library."

The second reason is the wide dissemination of these texts among readers of that time. In contrast, poetic and dramatic works of the time, even when published, were rarely disseminated outside of the circle of people to whom they were addressed or by whom they were to be performed. Historical memoirs and pilgrimage works almost always remained in manuscript form, until they were discovered by researchers in the 19th and 2oth centuries. Only biographical works and sermons were published in fairly large numbers and found a wide readership. In contrast, the majority of polemical works were intended for publication and enjoyed a significant public response.

$1 \quad$ Istoriia ukrainskoi literatury [The History of Ukrainian Literature], vol. 1 (Kyiv: Vydavnytstvo AN URSR, 1954), 67. 
A third reason for the popularity of the polemical texts also exists. It involves the political circumstances that systematically included the polemical legacy in a tumultuous competition of pro-Russian and pro-European vectors of the development of Ukrainian culture in the 19th and 2oth centuries.

Literary-historical scholarship in the Russian Empire was formed in the first half of the 19th century. ${ }^{2}$ It was then, when the doctrine of "official nationality" ${ }^{3}$ was established in imperial ideology in response to the $1830-183^{4}$ Polish November Uprising, that in 1834 Mykhailo Maksymovych began teaching a course on the history of Russian literature at St. Volodymyr University in Kyiv. 5 The founding of the university was initiated by the odious Count Sergei Uvarov, author of the "Orthodoxy — autocracy — nationality" ideologeme, in order to overcome Polish cultural influence and to Russify Right Bank Ukraine. ${ }^{6}$

It is in this social context that the canon of texts of Ukrainian literature and a historical-literary model based on the antinomy "Orthodox Ukraine adversus the Catholic West" were beginning to take shape. Mykhailo Maksymovych himself, writing about the era of the Polish-Lithuanian Commonwealth, repeatedly mentions Jesuit intrigues, persecution of the Orthodox, forced conversion to the union, and Kyivan scribes "refuting through their writings the Jesuit slander of Orthodoxy." ${ }^{7}$ Maksymovych's close acquaintance and compiler of the first bio-bibliographic dictionary of East Slavic writers, Yevhenii Bolkhovitinov, the Metropolitan of Kyiv and Halych (18221837), provides information about the polemicists Andrii Muzhylovskyi, ${ }^{8}$ Dymytrii

2 P. A. Nikolaev, ed., Vozniknovenie russkoi nauki o literature [The Origins of Russian Literary Studies] (Moscow: Nauka, 1975), 225-62.

S. V. Udalov, "Teoriia ofitsialnoi narodnosti: mekhanizmy vnedreniia [The Theory of Official Nationality: Mechanisms of Implementation]," in Osvoboditelnoe dvizhenie v Rossii, ed. N. A. Troitskii (Saratov: Izdatelstvo Saratovskogo universiteta, 2006), 73-75; Andrei Zorin, Kormia dvuglavogo orla: Russkaia literatura i gosudarstvennaia ideologiia v poslednei treti XVIII i pervoi treti XIXveka [Feeding the Double-Headed Eagle: Russian Literature and State Ideology in Last Third of the 18th and First Third of the 19th Centuries] (Moscow: Novoe literaturnoe obozrenie, 2001), 341-44.

Tadeusz E. Domański, Epoka Powstania Listopadowego (Lublin: Norbertinum, 200o).

5 Volodymyr Zamlynskyi, "Patriarkh ukrainskoi nauky [The Patriarch of Ukrainian Scholarship]," in Kiev yavilsia gradom velikim...: Vybrani ukrainoznavchi tvory, ed. Mykhailo Maksymovych (Kyiv: Lybid, 1994), 15-17.

6 Tatiana Nizimova, "Ot pervykh kievskikh shkol do Universiteta Sviatogo Vladimira [From the First Kyiv Schools to Saint Volodymyr University]," Interdisciplinary Studies of Complex Systems 8 (2016): 81-88.

7 Mykhailo Maksymovych, Kiev yavilsia gradom velikim...: Vybrani ukrainoznavchi tvory [Kyiv Appeared as a Great City...: Selected Works in Ukrainian Studies] (Kyiv: Lybid, 1994), 84. 
Rostovskyi, ${ }^{9}$ Zakhariia Kopystenskyi, ${ }^{10}$ Ioanykii Galiatovskyi,,11 Lavrentii Zyzanii, ${ }^{12}$ Lazar Baranovych, ${ }^{13}$ Meletii Smotrytskyi, ${ }^{14}$ Petro Mohyla, ${ }^{15}$ and Stefan Yavorskyi. ${ }^{16}$ All of them represent one camp of polemicists, the Orthodox, with the exception of Meletii Smotrytskyi, a figure too prominent to have been ignored.

Sergei Uvarov's imperial nationalism was to some extent inspired by the ideas of the theorist of Jena Romanticism Friedrich Schlegel (1772-1829). ${ }^{17}$ Modern Ukrainian nationalism, formed amidst Kharkiv and Kyiv Romantics, was also strongly influenced by German Romanticism. Dmytro Chyzhevskyi, however, points to a selective approach to Western ideas and attitudes, their transformation and reformatting 18 "in specific forms of Eastern Christianity and Greek Orthodoxy, which imbued other aspects of the ideology with an eschatological flavor." ${ }^{19}$ An example of this was the programmatic document of the Cyril and Methodius Brotherhood, compiled by Mykola Kostomarov, eloquently entitled The Books of the Genesis of the Ukrainian People. It reflected the principle of making the Polish-Ukrainian conflict dependent on interfaith polemics, "when the lords and the Jesuits wanted to forcibly return Ukraine under their authority, so that Ukrainian Christians would believe everything the Pope would say." 20 Let us recall that Kostomarov planned to defend a master's thesis entitled "On the Causes and Nature of the Union in Western Russia" (1842), and was the first to publish the works of Ivan Vyshenskyi. ${ }^{21}$

Thus, the political situation of the Russian Empire paradoxically merged with the Cossack tenet of Romantic patriotism, consolidating the model of the polemical core of the literary life of the 16th-17th centuries. Texts of pro-Union, and even more so apologetic-Catholic content were removed from the national discourse. Nevertheless, the academic integrity of Russian archaeographers led to the publication in the Russian

\footnotetext{
9 Bolkhovitinov, Slovar istoricheskii, 76-87.

10 Bolkhovitinov, Slovar istoricheskii, 110-11.

11 Bolkhovitinov, Slovar istoricheskii, 130-32.

12 Bolkhovitinov, Slovar istoricheskii, $187-88$.

13 Bolkhovitinov, Slovar istoricheskii, 189-9o.

14 Bolkhovitinov, Slovar istoricheskii, 208-13.

15 Bolkhovitinov, Slovar istoricheskii, 26o-64.

16 Bolkhovitinov, Slovar istoricheskii, 304-09.

17 Zorin, Kormia dvuglavogo orla, 352-59.

18 Dmytro Chyzhevskyi, Narysy z istorii filosofii na Ukraini [Essays on the History of Philosophy in Ukraine] (Prague: Ukrainskyi hromadskyi vydavnychyi fond, 1931), 107.

19 Chyzhevskyi, Narysy z istorii filosofii, 108.

20 Mykola Kostomarov, Knyhy bytiia ukrainskoho narodu [The Books of the Genesis of the Ukrainian People] (Lviv; Kyiv: Novi shliakhy, 1921), 18.

21 Akty, otnosiashchiesia k istorii Yuzhnoi i Zapadnoi Rossii, sobrannye i izdannye Arkheographicheskoi komissiei: Tom 1-15 [Acts Relating to the History of Southern and Western Russia, Collected and Published by the Archaeological Commission: Vols. 1-15], vol. 2: 1599-1637, ed. Mykola Kostomarov (Saint Petersburg: Tipografiia Eduarda Pratsa, 1865), 205-70.
} 
Historical Library the texts of not only Zakhariia Kopystenskyi and Khrystofor Filalet, but also of Piotr Skarga, Lev Krevza, and Ipatii Potii. The polemical texts were divided into three volumes with the title Monuments of Polemical Literature in Western Rus (vol. 4-1878; vol. 7-1882; vol. 19-1903). The general style of interpretation of interfaith polemics was determined by an anti-Catholic stance, which turned into a "Synodal Act of Reunification with Orthodoxy" for the Union Kyiv Metropolis in 1839.22 After the 1863 Polish January Uprising ${ }^{23}$ it was the turn of the Kholm Diocese, destroyed by the "Act of Reunification of the Kholm Greek Union Church with the Orthodox All-Russian Church" of $1875 \cdot{ }^{24}$

The Bolshevik coup of 1917 and the occupation of the Ukrainian People's Republic by Soviet Russia ushered in a period of openly anti-religious policy, ${ }^{25}$ especially ruthless against the Catholic Church. ${ }^{26}$ Confessional in nature texts were practically removed from the literary canon. The situation changed markedly after Joseph Stalin's agreement on cooperation with the episcopate of the Russian Orthodox Church ${ }^{27}$ and the forcible liquidation of the Ukrainian Greek Catholic Church (UGCC). ${ }^{28}$ Early modern Orthodox publicistic literature began to be interpreted in a new ideological paradigm as a factor in the opposition of Eastern European nations to the "expansionist policy of the Vatican." A bipolar scheme of international relations, according to which the "socialist world" stood against the "capitalist West," was transposed to times long gone. Orthodox and

22 Atanasii Velykyi, OSBM, Z litopysu khrystyianskoi Ukrainy [From the Chronicle of Christian Ukraine], vol. 7: The 18th-19th Centuries (Rome: Vydavnytstvo oo. Vasyliian, 1975), 263-72; Sofron Mudryi, bishop, OSBM, Narys istorii Tserkvy v Ukraini [An Essay on the History of the Church in Ukraine ], 4th ed. (Lviv: Misioner, 2010), 377-85.

23 Jarosław Szarek, Powstanie styczniowe: Zryw wolnych Polaków (Kraków: Wydawnictwo AA, 2014).

24 Nadiia Stokolosa and Ruslana Sheretiuk, Drama Tserkvy: Do istorii skasuvannia Hreko-Uniatskoi Tserkvy v Rosiiskii imperii ta vykorinennia yii dukhovno-kulturnykh nadban [The Drama of the Church: Toward the History of the Liquidation of the Greek-Uniate Church in the Russian Empire and of the Eradication of Its Spiritual and Cultural Heritage] (Rivne: PP DM, 2011), 119-20.

25 Yaroslav Shchapov, ed., Russkaia Pravoslavnaia Tserkov i kommunisticheskoe gosudarstvo, 1917-1941: Dokumenty ifotomaterialy [The Russian Orthodox Church and the Communist State, 1917-1941: Documents and Photographs] (Moscow: Izdatelstvo Bibleisko-Bogoslovskogo Instituta sv. Ap. Andreia, 1996), 10-322.

Olga Litzenberger, Rimsko-Katolicheskaia Tserkov v Rossii: Istoriia i pravovoe polozhenie [The Roman Catholic Church in Russia: History and the Legal Status] (Saratov: Povolzhskaia Akademiia gosudarstvennoi sluzhby, 2001), 183-304.

Dmitrii Pospelovskii, Russkaia Pravoslavnaia Tserkovv XXveke [The Orthodox Church in the History of Russia] (Moscow: Respublika, 1995), 187-91.

Bohdan Botsiurkiv, Ukrainska Hreko-Katolytska Tserkva i Radianska derzhava (1939-1950)

[The Ukrainian Greek Catholic Church and the Soviet State, 1939-1950], trans. by Nataliia Kochan (Lviv: Vyd-vo UCU, 2005), 89-200; Volodymyr Serhiichuk, ed., Likvidatsiia UGKTs (1939-1946): Dokumenty radianskykh orhaniv derzhavnoi bezpeky [The Liquidation of the UGCC, 1939-1946: Documents of Soviet State Security Services], 2 vols. (Kyiv: PP Serhiichuk M. I., 2006). 
Catholic polemicists began to be perceived as defenders of the interests of hostile classes and societies. Evidence of this was sought, as was then the practice, in the Marxist classics:

The so-called religious wars of the 16 th century were primarily about material class interests, and these wars were class struggles in much the same way as the later internal struggles of England and France. When these class struggles manifested themselves under religious cover, hiding the interests, needs, and aspirations of individual classes under a religious cloak did not change anything and could easily be clarified by the circumstances of the time. ${ }^{29}$

The new situation allowed for the legitimization of the most radically anti-Catholic portion of the polemical texts. In 1949 a Textbook of Ancient Ukrainian Literature was published, edited by Oleksandr Biletskyi. It contained excerpts from the works of Herasym Smotrytskyi, Ivan Vyshenskyi, Meletii Smotrytskyi, Zakhariia Kopystenskyi, the Apokrysys and Perestoroha. ${ }^{30}$ Subsequently, the textbook was republished twice, in $195^{2}$ and 1967 , and until the end of the 20 th century remained as the main source of polemical texts for the general reader. Oleksandr Biletskyi also prepared a chapter entitled "Polemical Literature: Ivan Vyshenskyi" for the first Soviet sanctioned course on the history of Ukrainian literature. ${ }^{31}$ Ivan Vyshenskyi's works began to be studied in high school (grade 8), were published first in Soviet Leningrad and then in Kyiv, ${ }^{32}$ and were later published in the "School Library" series. ${ }^{33}$ Poltava literary scholar Petro Zahaiko published a monograph with the telling title Ukrainian Polemicist Writers of the Late 16th-Early 17th Centuries in the Struggle Against the Vatican and the Union. ${ }^{34}$ And in Drohobych in the mid-195os, Porfyrii Yaremenko embarked on research focusing on polemical literature. ${ }^{35}$

29 Friedrich Engels, The Peasant War in Germany, trans. by Moissaye J. Olgin (New York: International Publishers, 1966), 21.

Oleksandr Biletskyi, comp., Khrestomatiia davnioi ukrainskoi literatury (do kintsia XVIII st.) [A Textbook of Ancient Ukrainian Literature], 3rd ed. (Kyiv: Radianska shkola, 1967), 112-73.

31 Oleksandr Biletskyi, ed., Istoriia ukrainskoi literatury [The History of Ukrainian Literature], vol. 1 (Kyiv: Vydavnytstvo AN URSR, 1954), 67-75.

32 Ivan Vishenskii, Sochineniia [Works], comp. I. P. Yeriomin (Moscow; Leningrad: Izdatelstvo AN SSSR, 1955); Ivan Vyshenskyi, Vybrani tvory [Selected Works], comp. I. P. Yeriomin (Kyiv: Derzhlitvydav URSR, 1959).

33 Ivan Vyshenskyi, Vybrani tvory [Selected Works], comp. V. L. Mykytas (Kyiv: Dnipro, 1972).

34 Petro Zahaiko, Ukrainski pysmennyky-polemisty kintsia XVI-pochatku XVII st. v borotbi proty Vatykanu i unii [Ukrainian Writers-Polemicists of the End of the 16th and Early 17th Centuries in a Struggle Against the Vatican] (Kyiv: Vydavnytstvo AN URSR, 1957).

Ye. Pshenychnyi, ed., Palkyi trudar nauky ta osvity: Zbirnyk na poshanu profesora Porfyriia Yaremenka [A Dedicated Researcher in Scholarship and Education: Collection in Honor of Porfyrii 
A tendentious interpretation of the polemical works conveniently suited the Soviet model of the history of Ukrainian literature. First, the confessional intransigence of Orthodox authors was to confirm the atheistic assessment of religion as a source of discord and societal confrontation. Second, the works of authoritative theologians enshrined in the mass consciousness propagandistic stereotypes on the aggressive nature of the Catholic Church and the betrayal of the faith by the founders of the Brest Union. Third, the focus on polemical writing with its archaic rhetoric in the body of early modern texts confirmed the preservation of a medieval character in Ukrainian literature until the 18th century. This literature was imbued with an "ancient" definition, thus distanced from other European literatures of the Renaissance and Baroque, instead positioned in the Russian-Byzantine civilizational sphere. And, fourth, the ideological pragmatism of the polemicists meshed perfectly with the methodological strategy of Marxist-Leninist aesthetics, which interpreted artistic creativity as a form of the manifestation of certain societal ideas.

Meanwhile, Dmytro Chyzhevskyi's Prague publications, consisting of the second volume of The History of Ukrainian Literature (1942) ${ }^{36}$ and three issues of The Ukrainian Literary Baroque (1941-1944), ${ }^{37}$ offered a somewhat alternative model. Essays comprising The Ukrainian Literary Baroque did not include consideration of polemical texts whatsoever, and in the second edition of The History of Ukrainian Literature sections on polemical literature were deprived of priority and relegated to the background. Noting the genius of Ivan Vyshenskyi, Chyzhevskyi nevertheless had the boldness to originally comment on interfaith polemics: "This brilliant page of Ukrainian cultural history is not brilliant in a literary way." 38 The criterion for assessing the significance of works in a historical and literary perspective is not as important for him as are their poetics, style, and artistic imagery. Thus, in the Baroque era, polemical treatises from Chyzhevskyi's point of view are inferior to verse literature, epics and novels, drama, sermons, and historical prose. Against this background, even such prominent polemical

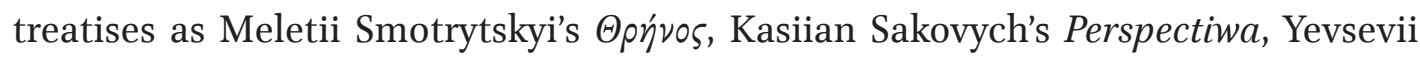
Pimin's $\Lambda \vartheta^{\prime} \circ$ s, and Zakhariia Kopystenskyi's $\Pi \alpha \lambda \imath \nu \omega \delta i a$ are only briefly mentioned. In them, Chyzhevskyi singles out "baroque splendor and intemperance in expressions, anecdotes, and attacks." 39 Chyzhevskyi's "Renaissance" and "Baroque" sections were preserved without significant changes in a synthetic course on the history of Ukrainian literature, published in 1956 in New York.

Yaremenko] (Drohobych: Kolo, 2018), 155-6o (bibliography).

Dmytro Chyzhevskyi, Istoriia ukrainskoi literatury [The History of Ukrainian Literature], vol. 2:

IV. Renesans ta reformatsiia. V. Barok (Prague: Vydavnytstvo Yuriia Tyshchenka, 1942).

Dmytro Chyzhevskyi, Ukrainskyi literaturnyi barok. Narysy [The Ukrainian Literary Baroque:

Essays], 3 parts (Prague: Vydavnytstvo Ukrainskoho istoryko-filolohichnoho tovarystva, 1941-1944).

Chyzhevskyi, Istoriia ukrainskoi literatury, 17. 
Understandably, the works of Dmytro Chyzhevskyi, as a representative of the Ukrainian emigration, were a priori rejected by official Soviet scholarship. Oleksandr Biletskyi, a leading literary scholar of the Ukrainian SSR, accused Chyzhevskyi's methodology of separating literature from the historical conditions of people's lives and retreating "into a sphere of purely immanent, purely formalistic study." 40 Nevertheless, since the late 1950s, a Kyivan group of researchers of Ukrainian literature of the 16th to the 18th centuries gradually focused their research on this sphere. In 1964 its informal leader, Leonid Makhnovets, published a monograph entitled Satire and Humor in Ukrainian Prose of the 15th-18th Centuries, ${ }^{41}$ in which he drew attention to the style of polemical prose. And in the first volume of The History of Ukrainian Literature, edited under Makhnovets's direction, the chapters on polemical prose were freed as much as possible from propagandistic stereotyping, were broadened by the inclusion of works by Catholic authors, and enriched by an analysis of the style of polemical texts. ${ }^{42}$

The Prague Spring of 1968, the arrest of Bishop Vasyl Velychkovskyi on January 23, 1969, the mass repressions of 1972, and the appointment of Valentyn Malanchuk to head the ideological department of the CPU Central Committee on October 10, 1972, marked the beginning of an aggressive campaign to smear the UGCC. Polemical literature was involved as a tool in this campaign, which implied the inevitable ideologization of the style of presentation. A telling example of this approach was the celebration of the 4ooth anniversary of the founding of the Lviv Assumption Brotherhood, held on April 20-22, 1988. A scholarly conference to mark the occasion, after a revision by party institutions, was named "Progressive Socio-Political Thought in the Struggle Against Feudal Reaction and Catholic-Uniate Expansion in Ukraine.”

The restoration of Ukraine's state independence on August 24, 1991 and the beginning of a decolonization process created optimal preconditions for a new reading of polemical texts of the early modern period. Access to resources was facilitated, both through the opening of library collections and through the publication by Harvard University of the Library of Ancient Ukrainian Literature, with the enlistment of the latest information technologies and the transfer of rare editions of the past into electronic media. The works of Western researchers on the subject become available, of which David Frick's book ${ }^{43}$ and articles on Meletii Smotrytskyi should be noted.

40 Oleksandr Biletskyi, "Do pytannia pro periodyzatsiiu istorii dozhovtnevoi ukrainskoi literatury [To the Question About the Periodization of Pre-October Ukrainian Literature]," in Zibrannia prats by Oleksandr Biletskyi, vol. 2 (Kyiv: Naukova dumka, 1965), 65. Leonid Makhnovets, Satyra i humor ukrainskoi prozy XVI-XVIII st. [Satire and Humor in Ukrainian Prose of the 16th-18th Centuries] (Kyiv: Naukova dumka, 1964).

Ye. Kyryliuk, ed., Istoriia ukrainskoi literatury [The History of Ukrainian Literature], vol. 1: Davnia literatura (XI - persha polovyna XVIII st.), ed. Leonid Makhnovets (Kyiv: Naukova dumka, 1967), 231-82, 377-87. 
However, new and unexpected obstacles appeared. The legalization of the UGCC was accompanied by an outbreak of inter-church confrontation in Western Ukraine, in which the opponents of the UGCC were the Russian Orthodox Church and the Ukrainian Autocephalous Orthodox Church, and later the Ukrainian Orthodox Church of the Kyiv Patriarchate. The post-communist governments of Ukraine and Russia attempted to use the Orthodox churches for their ideological support, resorting to state protectionism. Communists, "progressive socialists," and various chauvinistic Russian organizations claimed to be the defenders of a single Orthodox Church on postSoviet territory. Also appearing were all sorts of Cossack organizations focused on the mythological image of "Orthodox Knights" of a Mykola Hohol Taras Bulba mould. This made research on interfaith polemics of the past dependent on the current political situation, obligating extreme carefulness and sensitivity on the part of researchers.

Attempts to actualize interreligious polemics of the past were manifested in particular in several canonization processes. First, the Ukrainian Orthodox Churches (UOC) of the Kyiv (KP) and Moscow Patriarchates (MP) rushed to be first to proclaim Metropolitan Petro Mohyla a saint: the UOC-MP on December 6, 1996,44 and the UOCKP on December 12, 1996.45 Later, on July 17, 2011, a part of the Ukrainian Autocephalous Orthodox Church, headed by Metropolitan Mefodii Kudriakov, solemnly glorified as "pious hetman" Petro Konashevych-Sahaidachnyi, organizer of the restoration of a separate Kyiv Orthodox Metropolitanate in 1620.46 And on July 20, 2016, the UOCMP canonized the leading polemicist of the turn of the 16th-17th centuries, Ivan Vyshenskyi. ${ }^{47}$ With the support of UOC-KP Patriarch Filaret Denysenko, the Polishlanguage anti-Catholic treatises $\Theta p \eta ́ v o \varsigma$ (by Meletii Smotrytskyi) ${ }^{48}$ and $\Lambda$ i Mohyla ${ }^{49}$ were republished with parallel Ukrainian translations. The apologization of the bearers of a certain confessional doctrine was combined with the simplification of their theological and ideological positions, purely literary and artistic aspects of the works being ignored.

44 “Piotr (Mogila)," Drevo: Otkrytaia pravoslavnaia entsyklopediia, accessed May 5, 2019, https:// drevo-info.ru/articles/20675.html.

“Arkhiiereiskyi Sobor UPTs Kyivskoho Patriarkhatu 12 hrudnia 1996 roku [The Bishops' Council of the UOC of the Kyiv Patrirachate, December 12, 1996]," accessed May 9, 2019, https://www. cerkva.info/church/arkhiiereiskyi-sobor-upts-kyivskoho-patriarkhatu-12-hrudnia-1996-roku. "UAPTs proholosyla Sahaidachnoho sviatym [The UAOC Has Proclaimed Sahaidachnyi a Saint]," Tyzhden.ua, accesssed May 9, 2019, https://tyzhden.ua/News/26815.

"Vydaiushchegosia afonskogo startsa i pisatelia-polemista prp. Ivana Vishenskogo Sviatogortsa Sinod UPTs prichislil k liku sviatykh [Eminent Athonite Elder and Writer-Polemicist Ivan Vyshenskyi Proclaimed a Saint by the Holy Synod of the UOC]," Pravoslavie.ru, accessed May 9, 2019, http://www.pravoslavie.ru/95525.html.

48 Meletii Smotrytskyi, Trenos abo Plach Yedynoi Sviatoi Pomisnoi Apostolskoi Tserkvy... [Threnos, or the Lament for the One Holy Universal Apostolic Eastern Church], trans. and preface Rostyslav Radyshevskyi (Kyiv: Talkom, 2015). 
Against this background, Serhii Babych's candidate dissertation "Meletii Smotrytskyi's Works in the Context of the Early Ukrainian Baroque," defended in 2002 and published in 2009, stands out.50 It marked fundamental methodological changes in the interpretation of polemical texts: freedom from ideological dependence, the competent and careful inclusion of Ukrainian texts of the early $17^{\text {th }}$ century into the context of contemporary European culture, and a careful analysis of the poetics and rhetoric of the texts. The untimely death of the author, who had just turned 29 in 2004, marked an irreparable loss for Ukrainian literary studies.

Natalia Poplavska's doctoral dissertation "Ukrainian Polemical and Publicistic Prose of the End of the 16th to the Beginning of the 18th Centuries: Modern Reception and Reinterpretation," defended in 2008 on the basis of a monograph published a year earlier, also had a positive effect..$^{51}$ Sections of this monograph were partially included in the 12-volume History of Ukrainian Literature, ${ }^{52}$ thus identifying interpretive strategies that claim a normative status. And Ruslan Tkachuk's studies on the literary work of Ipatii Potii, Uniate Metropolitan and the first ideologue of the Kyivan Metropolitanate in union with Rome, marked the overcoming of the previous one-sided nature of the interpretation of literary polemics. ${ }^{53}$

Thus, at the beginning of the 21st century certain optimistic tendencies were defined, which open the prospect of a completely new reading of the body of polemical texts of the early modern period and a corresponding adjustment of the model of Ukrainian literary history. At the same time, the most important principle that should form the basis of new interpretive strategies seems to be the understanding of polemics as dialogue, not as an incorrigible quarrel between implacable enemies, but a dialogue that reflects Rus's civilizational search for its identity amidst geopolitical change in the Reformation era.

The communicative context in which texts are exchanged can hardly be limited by the ethnic boundaries of the Ukrainian people. First of all, the content of interfaith polemics is carried out with the active participation of texts of foreign origin. This is the patristic heritage that came to the communicative sphere of the Polish Commonwealth

50 Serhii Babych, Tvorchist Meletiia Smotrytskoho v konteksti rannioho ukrainskoho baroko [Meletii Smotrytskyi's Works in the Context of the Early Ukrainian Baroque] (Lviv: Svichado, 20o9).

$51 \quad$ Nataliia Poplavska, Polemisty. Rytoryka. Perekonuvannia: Ukrainska polemichno-publitsystychna proza kintsia XVI - pochatku XVII st. [Polemicists. Rhetoric. Persuasion: Ukrainian Polemical and Publicistic Prose of the End of the 16th to the Beginning of the 17th Centuries] (Ternopil: TNPU, 2007). Vitalii Donchyk, ed., Istoriia ukrainskoi literatury [The History of Ukrainian Literature], vol. 2: Davnia literatura (druha polovyna XVI —XVIII st.), ed. Mykola Sulyma (Kyiv: Naukova dumka, 2014), 98-154.

53 Ruslan Tkachuk, Tvorchist mytropolyta Ipatiia Potiia ta polemichna literatura na mezhi XVIpochatku XVII st.: Dzherela. Rytoryka. Dialoh [The Works of Metropolitan Ipatii Potii and Polemic Literature of the Late 16th-Early 17th Centuries: Sources. Rhetoric. Dialogue] (Kyiv: Vydavnychyi dim Dmytra Buraho, 2011). 
mainly through Latin translations, the theological works of medieval thinkers, and the polemical works of Polish (Piotr Skarga, Benedykt Herbest, Benedykt Paweł Boym, among others) or Russian (Maxim the Greek) authors.

In addition, the very borders of Rus as an ethnocultural or rather ethnoconfessional concept are not identical to modern ideas about the Ukrainian nation. The base indicator of "Rusness" is faith, in fact, not even faith, but the form of its confession: the Eastern (Byzantine) rite in its Kyiv-Galician version. It is difficult to clearly define the border between the Ukrainian and Belarusian segments of this confessional sphere; except for perhaps the old administrative borders of the Crown of the Kingdom of Poland and the Grand Duchy of Lithuania setting against each other Ruthenians living in the territory of the Crown and "Lithuanians," i. e. Belarusians under Lithuanian jurisdiction. And this is a very conditional differentiation: the core of the Orthodox and Uniate communities of the capital of the Grand Duchy of Lithuania, Vilnius, was largely composed of Ruthenians-Ukrainians. Somewhere in the northeast, Moscow, one of the main historical opponents of the Polish-Lithuanian Commonwealth and at the same time an ambitious contender to inherit the status of the center of world Orthodoxy from Turkish-occupied Constantinople, menacingly arose. In search of external support, after 1620 Kyivan Orthodox scribes and their defenders from the Zaporozhian Sich increasingly turned their eyes to the East. The artificial Greek term " $\mu \varepsilon \gamma \alpha \dot{\lambda} \lambda \eta$ 'P $\omega \sigma$ '́ $\alpha$," which originally signified the territory of Russian colonization, was transformed into a political trap — the mirage of a "Greater Russia," into which polemicists would be pushed by Orthodox fundamentalism.

The communicative context of the origin and functioning of Ukrainian polemical prose, thus, must take into account several dimensions. This includes a thousand year old polemic between the Byzantine East and Rome, which entered Rus in the 11th century. ${ }^{54}$ It focuses on the formulation of the doctrine of the proceeding of the Holy Spirit, "from the Father" or "from the Father and the Son," 55 the status of the bishop of Rome in the Ecumenical Church, speculation on the posthumous fate of the human soul (tax collection or purgatory), and fundamental or non-fundamental difference in the Byzantine and Latin rites. It also includes discussions of the Reformation era initiated by Martin Luther in 1517 concerning the relationship between hierarchy and the catholicity of the Church, the role of the laity in the ordering of church life, the doctrine of the sacraments, and the Transubstantiation of the Holy Gifts in the Eucharist. The profoundly operative Protestant community of the Polish Commonwealth, termed in the 16th century the "asylum for heretics," 56 took the most active part in these discussions. The situation at the Christian-Islamic border, on which

54 Feodosii Pecherskii, "Slovo... o vere krestianskoi i o latynskoi [A Word... On the Christian and Latin Faiths]," Trudy Otdela drevnerusskoi literatury 5 (1947): 170-73.

55 Valerii Zema, "Chomu i koly zyavylas polemika shchodo Filioque? [Why and When the Polemics on Filioque Arise?]," Ukraina v Tsentralno-Skhidnii Yevropi 17 (2017): 336-72.

56 Janusz Tazbir, Państwo bez stosów: szkice z dziejów tolerancji w Polsce w XVI-XVII w. (Warszawa: Państwowy Instytut Wydawniczy, 1967), 28. 
armed confrontations flared up time and time again, encouraged Ukrainian polemicists to enter the inter-religious dimension. ${ }^{57}$ The system of values, formed in the noble "Sarmatian" subculture, with its sensitivity to the cultivation of tradition, placed special emphasis on the rootedness of certain phenomena in an indigenous way of life and confession of faith. Faith is "old faith!" - appears here as a guarantee of identity, as does plain food, everyday clothes, and the old calendar with four obligatory fasts: "pillars on which our Rusian faith rests." 58

Thus, Ukrainian polemical prose of the end of the 16th to the beginning of the 18th centuries constitutes not only a large-scale textual mass, but also the hub of an intersection of communicative chains stretching between the Latin West and the Byzantine East, the Protestant North and the Orthodox South, and Christian and Islamic civilizations. And there is more. After all, for example, Ioanykii Galiatovskyi's treatise The Real Messiah (1669) raises the dialogue to a level of a meeting of Christianity and Judaism, and Inokentii Monastyrskyi's The Book of the Transubstantiation, Words by Christ's Judgment of the Holy Spirit and Dymytrii Tuptalo's Search for the Schismatic Bryn Faith (1709) deal with differences between the Rusian (Kyiv) and Moscow invariants of the Eastern Christian tradition.

In this thematic polyphony it is easy to get confused and focused on individual detail, losing the scope of the whole picture. This often happened when researchers' attention was focused on disputes over the legal aspects of the Brest Union of 1596, the astronomical basis of Pope Gregory XIII's calendar reform of 1582 , and social nuances of the religious policy of the Polish-Lithuanian Commonwealth among other issues. A countless number of details in polemical discourse truly deserve special attention. However, a comprehensive interdisciplinary approach can reveal to a literary researcher of this discourse an invaluable tool for developing a productive model of the history of Ukrainian literature of early modern times. And this tool may become the mode of "Rusian" identity.

Listening carefully to polemical disquietude and blocking out all sorts of extraneous noise allows us to embark on a dramatic search for our own identity in determining Rus's place on the civilizational map of the world, between East and West, in tracing the longevity of church ritual and cultural tradition, and in linguistic experiments on a semiotic palette.

The inertia of medieval universalism prompted the polemicists to position themselves in a wider denominational dimension, apart from Christian ecumenism. The dichotomization of this ecumenism provided them with a dilemma in choosing a

57 Stanislav Orikhovskyi, Tvory [Works], trans. Volodymyr Lytvynov (Kyiv: Dnipro, 2004), 71-117; Svitlana Sukharieva, "Antyturetska polskomovna proza XVII st.: ukrainskyi aspekt [Anti-Turkish Prose Written in Polish in the 17th Century: The Ukrainian Aspect]," Kyivski polonistychni studii XXVI (2016): 154-63.

$5^{8}$ Volodymyr Krekoten, comp., Ukrainska literatura XVII st.: Synkretychna pysemnist. Poeziia. Dramaturhiia. Beletrystyka [Ukrainian Literature of the 17th Century: Syncretic Writings, Poetry, Drama, Fiction] (Kyiv: Naukova dumka, 1987), 145. 
system of civilizational coordinates with an appropriate point of reference and value dimensions. The Greco-centric paradigm not only focused on the protection of the Byzantine model of the church system and theological concepts and forms of faith inherited from Eastern Church Fathers, it also influenced the rhetorical strategy of polemical discourse, the selection of topoi and the language palette of the authors. After all, the Church Slavonic language was perceived as the lingua franca of the Slavic peoples who were part of the Byzantine-Orthodox sphere. Thus, its use, or at least the purposeful archaization of its style, revealed a gravitation to the Christian East.

Ivan Vyshenskyi contrasts Piotr Skarga's ironic mockery of the Church Slavonic language with its apology: "For I'll tell you a great secret: the devil has so much envy of the Slavonic language, he barely lives from wrath... it is the most fruitful of all languages and beloved by God." ${ }^{9}$ In this polemical strategy the boundaries of the concept of "Rus" (increasingly "Little Rus") are outlined by the sphere of the spread of the Byzantine rite with the Church Slavonic language of worship and hereditary ties with the country ruled by the "Rusian" Rurik family. They coincide, to some extent, with the canonical territory of the Kyivan Metropolitanate of the Patriarchate of Constantinople.

The integration of Ukrainian elites into the hierarchical structure of the PolishLithuanian Commonwealth was accompanied by a reconsideration of the concept of "Rusianness" as a factor of self-identification. Linguistic and confessional separateness receded into the background, giving way to national patriotism, a sign of which was devotion to the king and to democratic freedoms of the aristocratic republic. Already in the times of Stanislaw Orikhovskyi the ideologeme gente Ruthenus natione Polonus definitively defined the mentality of the aristocratic families of Galicia, Volyn, Podillia, and Naddniprianshchyna. The polemical texts were largely composed in this environment and reflected its values.

This can be related to the stylistic changes that reflected the entry of polemical texts into the national communicative sphere of the Polish-Lithuanian Commonwealth. From the 159 os to the 168 os the Polish language dominated polemical discourse. Latinisms became an important element of the style. A very noticeable trend was the reception of the works of the Greek Fathers of the Church through Latin mediation. On the one hand, the Greek language was incomparably less common in Ukraine than Latin. On the other hand, the publication of the patristic texts of the Hellenistic Mediterranean in the original had just begun, while their Latin translations had long ago entered the theological culture of the European tradition. The Scriptures were also often quoted in the Vulgate, officially recognized by the Council of Trent in 1546 as the normative version of the Bible. ${ }^{60}$

The Brest Union of 1596 became an important, but by no means only, stage in the search by the educated Rusian class for a proper place in the new multicultural and

59 Vyshenskyi, Vybrani tvory, 23.

6o Arkadiusz Baron, priest and Henryk Pietras, priest, SJ, comps, Dokumenty Soborów

Powszechnych: Tekst taciński, polski, vol. 4: Lateran V. Trydent. Watykan I (1511-1870), (Kraków:

WAM, 2005), 210-15. 
multiconfessional Europe. Following fierce disputes over the right of the episcopate of the Kyivan Metropolitanate to determine its canonical affiliation independent of Constantinople and Moscow, the polemics rose to the level of historical retrospective and correct interpretations of patristic ecclesiology. A milestone in this process was the dialogue of Lev Krevza (Obrona jedności cerkiewnej, 1617) and Zakhariia Kopystenskyi

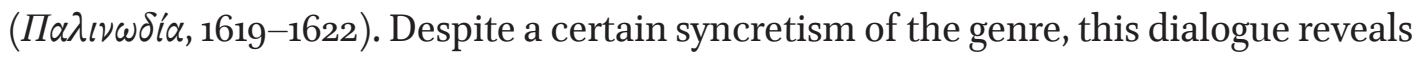
an interesting competition of poetic forms, which would soon erupt into a real war of Baroque metaphors between Kasian Sakovych (Perspectiwa, 1642) and a group of Kyivan scribes writing under the pseudonym "Eusebius Piminus" ( $\Lambda$ i 05,1644$).{ }^{61}$ Metaphor as trope, a term formed as a result of a very characteristic combination of two roots: $\mu \varepsilon \tau \dot{\alpha}-$ — "a transition from one place or state into another, a change" 62 and $\varphi \circ \alpha^{\alpha}$ - "carrying, carrying again," 63 is like a bridge between the virtual and real worlds, between theoretical considerations of authors and their life experiences. The polemical discourse that emerges during the dialogue encourages its participants to a metaphorization of the text, setting into play a wide range of plot material.

This became an important stimulus for a new reading of the history of the Kyiv Metropolitanate and the Rusian experience of holiness, which, in turn, resonated in the intensification of the development of historical prose and hagiography. The inevitable accommodation in a situation of dialogue to the partner's style prompted the Ukrainian authors to master Baroque rhetoric, which is most noticeable in the culture of the spoken word, but to some extent is also reflected in written practice. Relying on a wider readership and the example of the use of the living Polish language by opponents contributed to bringing the language of the polemical texts or their translations closer to the speaking practice of the addressees. This became a significant factor in improving the bookish version of the Ukrainian language.

In this fashion, the interfaith polemics of the Reformation and Counter-Reformation (16th-17th centuries) appeared as a leading channel for Ukrainian literature entering a broad communicative context, which on its part significantly affected structural changes in the domestic literary process. The theological issues of polemical texts are only one of many levels of their semiotics. Observations at other levels (topics, citations, inserted plots and phrases, rhetorical constructions, the language palette, the written escort, etc.) can reveal in this body of texts inconspicuous at first glance, but ultimately extremely important factors of change, significant in terms of literary perspective.

$61 \quad$ Ihor Isichenko, abp., Viina barokovykh metafor. Kamin Petra Mohyly proty pidzornoi truby Kasiiana Sakovycha [The War of Baroque Metaphors: Petro Mohyla's “Stone” Against Kasiian Sakovych's “Spyglass”] (Kharkiv: Akta, 2017).

62 John Groves, Rev., A Greek and English Dictionary, Comprising All the Words in the Writings of the Most Popular Greek Authors, with the Difficult Inflections in Them and in the Septuagint and New Testament (Philadelphia, 1855), 387.

63 Groves, A Greek and English Dictionary, 592. 


\section{Bibliography}

Akty, otnosiashchiesia $k$ istorii Yuzhnoi i Zapadnoi Rossii, sobrannye i izdannye Arkheographicheskoi komissiei: Tom 1-15 [Acts Relating to the History of Southern and Western Russia, Collected and Published by the Archaeological Commission: Vols. 1-15]. Vol. 2: 1599-1637, edited by Mykola Kostomarov. Saint-Petersburg: Tipografiia Eduarda Pratsa, 1865.

“Arkhiiereiskyi Sobor UPTs Kyivskoho Patriarkhatu 12 hrudnia 1996 roku [The Bishops' Council of the UOC of the Kyiv Patrirachate, December 12, 1996]." Accessed May 9, 2019. https://www.cerkva.info/church/arkhiiereiskyi-sobor-upts-kyivskohopatriarkhatu-12-hrudnia-1996-roku.

Babych, Serhii. Tvorchist Meletia Smotrytskoho v konteksti rannioho ukrainskoho baroko [Meletii Smotrytskyi's Works in the Context of the Early Ukrainian Baroque]. Lviv: Svichado, 2009.

Baron, Arkadiusz, priest and Henryk Pietras, priest, SJ, comps. Dokumenty Soborów Powszechnych: Tekst taciński, polski. Vol. 4: Lateran V. Trydent. Watykan I (15111870). Kraków: WAM, 2005.

Biletskyi, Oleksandr, comp. Khrestomatiia davnioi ukrainskoi literatury (do kintsia XVIII st.) [A Textbook of Ancient Ukrainian Literature]. 3rd ed. Kyiv: Radianska shkola, 1967.

Biletskyi, Oleksandr. "Do pytannia pro periodyzatsiiu istorii dozhovtnevoi ukrainskoi literatury [To the Question About the Periodization of Pre-October Ukrainian Literature]." In Oleksandr Biletskyi, Zibrannia prats, vol. 2, 50-71. Kyiv: Naukova dumka, 1965 .

Biletskyi, Oleksandr, ed. Istoriia ukrainskoi literatury [The History of Ukrainian Literature]. Vol. 1. Kyiv: Vydavnytstvo AN URSR, 1954.

Bolkhovitinov, Yevgenii, metropolitan. Slovar istoricheskii o byvshykhv Rossii pisateliakh dukhovnogo china Greko-Rossiiskoi Tserkvi [A Historical Dictionary of Greek-Russian Church Clergy Writers in Russia]. Moscow: Russkii Dvor; Sviato-Troitskaia Sergieva Lavra, 1995 .

Botsiurkiv, Bohdan. Ukrainska Hreko-Katolytska Tserkva iradianska derzhava (1939-1950)

[The Ukrainian Greek Catholic Church and the Soviet State, 1939-1950]. Translated by Nataliia Kochan. Lviv: Vyd-vo UCU, 2005.

Chyzhevskyi, Dmytro. Istoriia ukrainskoi literatury [The History of Ukrainian Literature].

Vol. 2: IV. Renesans ta reformatsiia. V. Barok. Prague: Vydavnytstvo Yuriia Tyshchenka, 1942.

Chyzhevskyi, Dmytro. Istoriia ukrainskoi literatury: Vid pochatkiv do doby realizmu [A History of Ukrainian Literature: From Its Emergence to the Age of Realism]. New York: UVAN, 1956.

Chyzhevskyi, Dmytro. Narysy z istorii filosofii na Ukraini [Essays on the History of Philosophy in Ukraine]. Prague: Ukrainskyi hromadskyi vydavnychyi fond, 1931. 
Chyzhevskyi, Dmytro. Ukrainskyi literaturnyi barok. Narysy [The Ukrainian Literary Baroque: Essays]. 3 parts. Prague: Vydavnytstvo Ukrainskoho istorykofilolohichnoho tovarystva, 1941-44.

Čyževs'kyj, Dmytro. A History of Ukrainian Literature (From the nth to the End of the 19th Century). 2nd ed. New York; Englewood, Col.: The Ukrainian Academy of Arts and Sciences; Ukrainian Academic Press, 1997.

Domański, Tadeusz Edward. Epoka Powstania Listopadowego. Lublin: Norbertinum, 2000.

Donchyk, Vitalii, ed. Istoriia ukrainskoi literatury [The History of Ukrainian Literature]. Vol. 2: Davnia literatura (druha polovyna XVI - XVIII st.), edited by Mykola Sulyma. Kyiv: Naukova dumka, 2014.

Engels, Friedrich. The Peasant War in Germany. Translated by Moissaye J. Olgin. New York, 1966.

Feodosii Pecherskii. "Slovo... o vere krestianskoi i o latynskoi [A Word... On the Christian and Latin Faiths]." Trudy Otdela drevnerusskoi literatury 5 (1947): 170-73.

Frick, David A.Meletij Smotryc'kyj. Cambridge, Mass.: Harvard Ukrainian Research Institute, 1995 .

Groves, John, Rev. A Greek and English Dictionary, Comprising All the Words in the Writings of the Most Popular Greek Authors; with the Difficult Inflections in Them and in the Septuagint and New Testament. Philadelphia, 1855.

Isichenko, Ihor, archbishop. Viina barokovykh metafor. Kamin Petra Mohyly proty pidzornoi truby Kasiiana Sakovycha [The War of Baroque Metaphors: Petro Mohyla's "Stone" Against Kasiian Sakovych's "Spyglass"]. Kharkiv: Akta, 2017.

Kostomarov, Mykola. Knyhy bytiia ukrainskoho narodu [The Books of the Genesis of the Ukrainian People]. Lviv; Kyiv: Novi shliakhy, 1921.

Krekoten, Volodymyr, comp. Ukrainska literatura XVII st.: Synkretychna pysemnist. Poeziia. Dramaturhiia. Beletrystyka [Ukrainian Literature of the 17th Century: Syncretic Writings, Poetry, Drama, Fiction]. Kyiv: Naukova dumka, 1987.

Kyryliuk, Ye., ed. Istoriia ukrainskoi literatury [The History of Ukrainian Literature]. Vol. 1: Davnia literatura (XI - persha polovyna XVIII st.), edited by Leonid Makhnovets. Kyiv: Naukova dumka, 1967.

Litzenberger, Olga. Rimsko-Katolicheskaia Tserkovv Rossii: Istoriia i pravovoe polozhenie [The Roman Catholic Church in Russia: History and the Legal Status]. Saratov: Povolzhskaia Akademiia gosudarstvennoi sluzhby, 2001.

Makhnovets, Leonid. Satyra i humor ukrainskoi prozy XVI-XVIII st. [Satire and Humor in Ukrainian Prose of the 16th-18th Centuries]. Kyiv: Naukova dumka, 1964.

Maksymovych, Mykhailo. Kiev yavilsia gradom velikim... Vybrani ukrainoznavchi tvory [Kyiv Appeared as a Great City...: Selected Works in Ukrainian Studies]. Kyiv: Lybid, 1994.

Smotrytskyi, Meletii. Trenos abo Plach Yedynoi Sviatoi Pomisnoi Apostolskoi Tserkry... [Threnos, or the Lament for the One Holy Universal Apostolic Eastern Church]. Translated and preface by Rostyslav Radyshevskyi. Kyiv: Talkom, 2015. 
Mudryi, Sofron, bishop, OSBM. Narys istorii Tserkvy v Ukraini [An Essay on the History of the Church in Ukraine]. 4th ed. Lviv: Misioner, 2010.

Nizimova, Tatiana. "Ot pervykh kievskikh shkol do Universiteta Sviatogo Vladimira [From the First Kyiv Schools to Saint Volodymyr University]." Interdisciplinary Studies of Complex Systems 8 (2016): 49-129.

Orikhovskyi, Stanislav. Tvory [Works]. Translated by Volodymyr Lytvynov. Kyiv: Dnipro, 2004.

Pshenychnyi, Ye., ed. Palkyi trudarnauky ta osvity:Zbirnykna poshanu profesora Porfyriia Yaremenka [A Dedicated Researcher in Scholarship and Education: Collection in Honor of Porfyrii Yaremenko]. Drohobych: Kolo, 2018.

Mohyla, Petro. Litos. Translated and preface by Rostyslav Radyshevskyi. Kyiv: Talkom, 2018.

"Piotr (Mogila)." Drevo: Otkrytaia pravoslavnaia entsyklopediia. Accessed May 9, 2019. https://drevo-info.ru/articles/20675.html.

Poplavska, Nataliia. Polemisty. Rytoryka. Perekonuvannia: Ukrainska polemichnopublitsystychna proza kintsia XVI-pochatku XVII st. [Polemicists. Rhetoric. Persuasion: Ukrainian Polemical and Publicistic Prose of the End of the 16th to the Beginning of the 17th Centuries]. Ternopil: TNPU, 2007.

Pospelovskii, Dmitrii. Russkaia Pravoslavnaia Tserkovv XXveke [The Orthodox Church in the History of Russia]. Moscow: Respublika, 1995.

Serhiichuk, Volodymyr, ed. Likvidatsiia UGKTs (1939-1946): Dokumenty radianskykh orhaniv derzhavnoi bezpeky [The Liquidation of the UGCC, 1939-1946: Documents of Soviet State Security Services]. 2 vols. Kyiv: PP Serhiichuk M. I., 2006.

Shchapov, Yaroslav, ed. Russkaia Pravoslavnaia Tserkov i kommunisticheskoe gosudarstvo, 1917-1941: Dokumenty i fotomaterialy [The Russian Orthodox Church and the Communist State, 1917-1941: Documents and Photographs]. Moscow: Izdatelstvo Bibleisko-Bogoslovskogo Instituta sv. Ap. Andreia, 1996.

Shulgin, V. Ya. Istoriia universiteta sviatogo Vladimira [The History of Saint Volodymyr University]. Saint Petersburg, 1860.

Stokolosa, Nadiia, and Ruslana Sheretiuk. Drama Tserkvy: Do istorii skasuvannia HrekoUniatskoi Tserkvy v Rosiiskii imperii ta vykorinennia yii dukhovno-kulturnykh nadban [The Drama of the Church: Toward the History of the Liquidation of the Greek-Uniate Church in the Russian Empire and the Eradication of Its Spiritual and Cultural Heritage]. Rivne: PP DM, 2011.

Sukharieva, Svitlana. "Antyturetska polskomovna proza XVII st.: ukrainskyi aspekt [Anti-Turkish Prose Written in Polish in the 17th Century: The Ukrainian Aspect]." Kyivski polonistychni studii XXVI (2016): 154-63.

Szarek, Jarosław. Powstanie styczniowe: Zryw wolnych Polaków. Kraków: Wydawnictwo AA, 2014.

Tazbir, Janusz. Państwo bez stosów: szkice z dziejów tolerancji w Polsce w XVI-XVII w. Warszawa: Państwowy Instytut Wydawniczy, 1967.

Tkachuk, Ruslan. Tvorchist mytropolyta Ipatiia Potiia ta polemichna literatura na mezhi XVI_pochatku XVII st.: Dzherela. Rytoryka. Dialoh [The Works of Metropolitan 
Ipatii Potii and Polemic Literature of the Late 16th-Early 17th Centuries: Sources. Rhetoric. Dialogue]. Kyiv: Vydavnychyi dim Dmytra Buraho, 2011.

"UAPTs proholosyla Sahaidachnoho sviatym [The UAOC Has Proclaimed Sahaidachnyi a Saint]." Tyzhden.ua. Accessed May 9, 2019. https://tyzhden.ua/News/26815.

Udalov, S. V. "Teoriia ofitsialnoi narodnosti: mekhanizmy vnedreniia [The Theory of Official Nationality: Mechanisms of Implementation]." In Osvoboditelnoe dvizhenie v Rossii, edited by N. A. Troitskii, 73-81. Saratov: Izdatelstvo Saratovskogo universiteta, 2006.

Velykyi, Atanasii, OSBM. Z litopysu khrystyianskoi Ukrainy [From the Chronicle of Christian Ukraine]. Vol. 7: The 18th-19th Centuries. Rome: Vydavnytstvo oo. Vasyliian, 1975 .

Vishenskii, Ivan. Sochineniia [Works]. Compiled by I. P. Yeriomin. Moscow; Leningrad: Izdatelstvo AN SSSR, 1955.

Nikolaev, P. A., ed. Vozniknovenie russkoi nauki o literature [The Origins of Russian Literary Studies]. Moscow: Nauka, 1975.

"Vydaiushchegosia afonskogo startsa i pisatelia-polemista prp. Ivana Vishenskogo Sviatogortsa Sinod UPTs prichislil k liku sviatykh [Eminent Athonite Elder and Writer-Polemicist Ivan Vyshenskyi Proclaimed a Saint by the Holy Synod of the UOC]. Pravoslavie.ru. Accessed May 9, 2019. http://www.pravoslavie.ru/95525. html.

Vyshenskyi, Ivan. Vybrani tvory [Selected Works]. Compiled by V. L. Mykytas. Kyiv: Dnipro, 1972.

Vyshenskyi, Ivan. Vybrani tvory [Selected Works]. Compiled by I. P. Yeriomin. Kyiv: Derzhlitvydav URSR, 1959.

Zahaiko, Petro. Ukrainskipysmennyky-polemisty kintsia XVI—pochatkuXVIIst.v borotbi proty Vatykanu i unii [Ukrainian Writers-Polemicists of the End of the 16th and Early 17th Centuries in a Struggle Against the Vatican]. Kyiv: Vydavnytstvo AN URSR, 1957.

Zamlynskyi, Volodymyr. "Patriarkh ukrainskoi nauky [The Patriarch of Ukrainian Scholarship]." In Mykhailo Maksymovych, Kiev yavilsia gradom velikim...: Vybrani ukrainoznavchi tvory, 10-31. Kyiv: Lybid, 1994.

Zema, Valerii. "Chomu i koly zyavylas polemika shchodo Filioque? [Why and When the Polemics on Filioque Arise?]." Ukraina v Tsentralno-Skhidnii Yevropi 17 (2017): $336-72$.

Zorin, Andrei. Kormia dvuglavogo orla:Russkaia literatura igosudarstvennaia ideologiia $v$ poslednei treti XVIII i pervoi treti XIX veka [Feeding the Double-Headed Eagle: Russian Literature and State Ideology in Last Third of the 18th and First Third of the 19th Centuries]. Moscow: Novoe literaturnoe obozrenie, 2001.

Ihor Isichenko was born on January 28, 1956. He is Archbishop of the Kharkiv and Poltava Eparchy of the Ukrainian Autocephalous Orthodox Church (1993-2020). Archbishop 
Isichenko studied at the Philological Faculty of A. M. Gorkiy Kharkiv State University (today the V. N. Karazin Kharkiv National University (1974-1979)) and since 1981 is on its academic staff at the Department of the History of Ukrainian Literature. Archbishop Isichenko's candidate thesis was entitled "The Kyiv Cave Patericon in Historical and Literary Processes From the End of the 16th to the 18th Centuries in Ukraine" (1987); his doctoral thesis was entitled "The Ascetic Literature of Kyivan Rus" (2009). His main focus of research is Ukrainian Baroque literature. Archbishop Isichenko has taught at the National University of Kyiv-Mohyla Academy since 2006. 